\title{
The Impact of the Sinsai Roo Jai Ton Project on the Development of Local Culture and Contemporary Performance in Northeastern Thailand
}

\author{
Pachaya Akkapram (พชญ อัคพราหมณ์) \\ Full-time Lecturer in the Music and Performing Arts section, Faculty of Fine \\ and Applied Arts, Khon Kaen University, Khon Kaen, Thailand \\ pachak@kku.ac.th
}

\begin{abstract}
This article discusses the diverse impacts of the Sinsai Roo Jai Ton research project based at Khon Kaen University from 2016 to 2019. Designed as a puppet performance by university students working with local artists in northeastern Thailand (Isan), the project inspired many other groups interested in making puppet performances by collaborating with local artists in Isan communities. Beyond collaborative performances, the project developed new interests in students who participated in the project and helped develop new types of teaching and learning, of research, and creating contemporary performances from artistic materials in local Isan communities such as narratives, stories, folk singing and playing music, murals, folk-dance, traditions and rituals, by using modern drama/theatre concepts and techniques as tools to find creative methods to present a new contemporary performance, to communicate new voices, ideas and aesthetics to audiences and to shape new modes of Isan identity.
\end{abstract}

\section{Keywords}

puppet performance - applied theatre - performance research - community arts

บทคัดย่อ

ผลกระทบของโครงการหุ่น สินไซรู้ใจตน ต่อการพัฒนาวัฒนธรรมท้องถิ่นและการแสดง ร่วมสมัยในภาคตะวันออกเฉียงเหนื้อ 
บทความนี้ศึกษาผลกระทบของโครงการวิจัยการแสดงหุ่น สินไซรู้ใจตน โดยดำเนินงานที่ มหาวิทยาลัยขอนแก่น ระหว่างปี พ.ศ. $2559^{-2562}$ การแสดงถูกออกแบบและนำเสนอโดย นักศึกษาที่ทำงานร่วมกับศิลปินในชุมชนอีสาน ผลการวิจัยพบว่าโครงการวิจัยและผลงานการ แสดงได้สร้างแรงบันดาลใจและเป็นต้นแบบแก่ผู้สนใจการแสดงหู่นที่พัฒนาจากฐานศิล ปะชุมชนเป็นวงกว้าง ผลกระทบอันมาจากองค์ความรู้ของโครงการวิจัยนี้ สามารถนำไปใช้ต่อยอด และพัฒนาการเรียนการสอน การวิจัย และการสร้างสรรค์การแสดงร่วมสมัยจากศิลปะชุมชนเช่น เรื่องเล่า นิทาน ดนตรีพื้นบ้าน หมอลำ บทร้องสรภัญญะ ภาพฮูปแต้ม การฟ้อนรำ ประเพณี และ พิธีกรรม โดยนำหลักคิดของละครตะวันตกมาใช้เป็นแกนในการพัฒนา และนำเสนอการแสดงรูป แบบใหม่ที่สามารถสื่อสารสุ้มเสียง ความคิด และสุนทรียะไปยังผู้ชม ตลอดจนนำเสนอตัวตนความ เป็นอีสานได้

\section{$1 \quad$ Introduction $^{1}$}

This research paper examines the main impacts of the research project entitled "Sinsai Dek Thewda - Khon Kaen University: Training Life Skills and Self-Understanding through the Process of Making Contemporary Isan Puppet Performance" which I led from 2016 to $2019 .{ }^{2}$ The project sought to develop cultural knowledge, life skills and self-understanding for Isan university students by creating a puppet performance with local artists from a nearby community. The project involved six Khon Kaen University students and me as facilitator from the Faculty of Fine and Applied Arts. We worked with local community artists to develop the students' local cultural knowledge and skills, which they used to devise an original contemporary puppet show called "Sinsai Roo Jai Ton" (loosely meaning "knowing [the Isan folk hero] Sinsai [helps you] know your heart [and Isan culture]"). Since 2017 this show has been performed for the public in more than 40 times, in both Thailand and abroad, including performances in Isan villages, in Thai universities and at international cultural and puppet festivals, including those in Laos and Vietnam.

The article will first consider the evolution of the "Sinsai Dek Thewda" project as background and context to better understand the various types, scales and dimensions of the impcts later discussed in detail.

1 See the photos of this article at the URL https://doi.org/10.6084/mg.figshare.13265564.

2 This was part of the three-year national umbrella project funded by the former Thailand Research Fund project (2016-2019) called "Performance Research: Doing Creative Research in Contemporary Thai Performing Arts" (RTA 5980010), and run by Professor Pornrat Damrhung out of Chulalongkorn University in Bangkok. In 2019 the Thailand Research Fund was folded into the new Thailand Science Research and Innovation (TSRI). 
From late 2016, six students from the Faculty of Fine and Applied Arts of Khon Kaen University and I began work on the project. Between December 2016 and August 2017, we created and developed puppet performances during six different 7 to 10 day short residencies, working with 10-12-year old members of the Dek Thewda Mor Lam Puppet Troupe at the Home Thong Sri Uppathum Theater in Nong No Tai village of Na Dun District in Mahasarakham Province, Thailand. ${ }^{3}$ The six students familiarized themselves with the villagers' traditional Isan lifestyle, and learned community arts like mural painting (called "Hoop Taem"), literature of the regional hero Sinsai, and the local Mor Lam style of folk singing. Local folk artists and masters, including Kru Thongchan Plaisuan, Kru Sawai Ladawan, and Kru Sombut Simla, trained the students in various artistic skills and offered them various experiences needed to create a puppet performance with the village youth. This first phase of the project focused on collaborative work and joint learning of group members through various community activities, while Kru Siang (Preecha Karun) and I were the main artists who designed and led the activities as project facilitators. ${ }^{4}$

The resulting puppet performance, called "Sinsai Dek Thewda," reinterpreted parts of the Sinsai legend cycle and linked it with current Isan social issues. Student team members created the storyline and developed the script with the facilitator, while Kru Thongchan composed lyrics. Students also made a set of large puppets out of sticky rice baskets and wickerwork by combining the knowledge from Kru Siang and their own creativity as drama students. The resulting puppets provided students with a new ensemble for creating and showing movement that differed from the puppets done by community's own Dek Thewda Puppet Troupe. The new performance style mixed storytelling with dialogues and Mor Lam and Phaya styles of singing to accompany the puppet movements, while folk music played by Kru Sombut and his team helped the puppet show communicate the story to Isan audiences. The resulting show was first performed at the Department of Drama in the Faculty of Fine and Applied Arts of Khon Kaen University in February 2017 and received comments from two experts, Dr. Songwit Phimphrakan, a Sinsai literary specialist and Dr. Tanatchaporn Kittikong, a contemporary performance

3 The six students were Ratchaneekorn Jantaharn, Tirattikan Srikhunmueng, Patsiri Pradabpachr, Pongsatorn Phutthakhot, Anugoon Mokchai, Veerapat Junlertrit.

4 Kru Siang is a noted contemporary ISAN folk artist known for designing and creating a new style of large folk rod puppets in made of sticky rice baskets and bamboo. Working from his village, he has developed a unique style of performing with a puppet troupe around Thailand. 
specialist. Their evaluations led the group to further develop the story, the presentation style, and puppeteering techniques during the second phase of the project.

To better communicate with the audience, Kru Siang and I adjusted the storyline by including conflicts between characters in each scene, reduced the dialogue, and clarified the puppet performance by adding various special techniques to better show the feelings and features of the characters with visual images onstage. Dr. Pornrat Damrhung was invited to see a puppet show workshop to practice puppet manipulation and movement and create distinguishing features of each character for the puppet team. After this workshop, the puppeteers had better concentration and both they their puppets could be coordinated, so their movement looked more realistic. This work permitted the different puppet characters to show their unique features in how they walked, laughed, flew, fought, etc.

The resulting puppet performance was called "Sinsai Dek Thewda" and was presented more than 20 times, including at the World Puppet Festival 2017 in Kanchanaburi Province, the Thai-ASEAN Contemporary Puppet Festival 2017 at the Ratchadamnoen Contemporary Art Center in Bangkok, and the MiniTheatre at the Department of Performing Arts in Mahasarakham University, as well as in various communities, such as Straw Puppet Festival and Boon Pawed Festival, where the team stepped up for the performance when Kru Sombut Simla could not come to play the kaen music for the show, leading students needed to be both puppeteers and musicians. In the second evaluation of the project by Dr. Jaruwan Thammawatra, an expert on Isan literature and arts, noted that "Isan performances have unique characteristics and differences. They must be simple and fun; there's no need to copy anyone's style. We have to find a path in our own way."

Once we ended our "residencies" in the village, I altered the working process to develop a more refined performance for the show under the name of "Sinsai Roo Jai Ton" between May and August 2017. We devised a new script to reflect the identity and story of the group, and developed stronger storylines based on input from the six participating students, while reducing the performance time to a more dynamic and flowing 40 minutes. Students also practiced and trained with the puppets more systematically. We had to change the team members due to limited training time and the great distance of some from their village homes. Six traditional music students from Khon Kaen University also replaced the youth of Dek Thewda Puppet Troupe. ${ }^{5}$ The music of the

5 The participants included: Kittithat Maleewan, Ratthapong Hongwern, Charnyuth Chuerboonmee, Charuphat Worrarat, Chirakit Unpim, Wittawut Najaikong. 
performance was made fuller and richer in this way, and with the three new puppeteers. ${ }^{6}$ The new fuller version of the performance was shown for the first time at "Kam Sad - Kam Vela" event at Sodsai Pantoomkomol Centre for Dramatic Arts, Faculty of Arts, Chulalongkorn University, on August 20-21, 2017. Performing in a theater effectively communicated the story to urban audiences. Although the Isan language was used throughout the performance, the actions of the characters, together with the story, ideas, movements of the puppets, and full lighting, color and sound elements allowed clear communication of the director's imagination and staged ideas to the audience.

After the Chulalongkorn University performance, in the second year (from October 2017 to September 2018), the team name changed to "Sinsai Khon Kaen University" due to its new base at my university. The team has travelled to perform more than 40 shows and workshops in various areas both in Thailand and abroad. Two changes were made for the musicians. Athit Krajangsri, who specialized in folk music joined as a music composer and directed the performance. This research became more of an "experimental space" to create a new Isan music and provided a collaborative opportunity for drama and folk music majors as a prototype of contemporary art creation using Isan arts and cultures as a base. Due to its success, it was used in many other projects too.

\section{$3 \quad$ Learning More than Art and Culture}

"Sinsai Dek Thewda" is a piece of creative practice-oriented performance research (see Damrhung 2018; Asmawi 2017; Smith and Dean 2012). Like other performance research, we did not only create work for performance on the stage through a collaborative process of university students and local artists in an Isan community. We also produced diverse repeatable results, such as the contemporary puppet performance Sinsai Roo Jai Ton, which has been performed in many times, both in Thailand and abroad, drawing interest from many people and groups. The project helped the six drama students and the musicians involved to discover their own potential and capacity by creating puppets. They learned to use them and perform on many stages during the two-year process, and to develop new individual and collective skills to solve problems. This working process became a prototype for others wanting to create performances by having young people learn with the local artists in nearby communities. This research project likewise produced a wide range of impacts

6 The new puppeteers were Sunita Thongsookdee, Ladapan Phansa-aot, Thaveep Soawaraj. 
in other arenas, such as in universities, schools, and communities, by expanding and extending applied drama research to processes that emphasize practical processes and concrete results for participants and communities (see Asmawi 2017; Barrett and Bolt 2007). Finally, the research could serve as a model for experimentation and creation of other types of performances grounded in local communities and including local artists.

The diverse results of this project thus produced forms of "cultural capital" in its participants, namely the knowledge, skills, and behaviors they gained by their involvement in this specific sociocultural context through teaching and learning (Bourdieu 1986). For Bourdieu, cultural capital "represents the immanent structure of the social world," and at any given time shapes what an individual may be able to do. Although there are many forms of cultural capital, they resemble one another in that each "takes time to accumulate and which, as a potential capacity to produce profits and to reproduce itself in identical or expanded form, contains a tendency to persist in its being." (Bourdieu 1986, 46) For the "Sinsai Dek Thewda" project, the cultural capital gained by participants emerged through their working with local artists in an Isan community over extended periods of time. This local, immersive learning helped them to generate new types of project-based practical learning focused on youth development which depended on applying traditional artistic knowledge to create contemporary performances for young people. All of this knowledge and new skills are also central to applied theater (see Prentki and Preston 2011). It provided a basis for new work in the future as well.

As signs of this new cultural capital, several types of "impact" emerged from the project, each working at different scales and dimensions beyond the project's original objectives. These included impacts on university teaching, school education, and community involvement. The impacts made the research more practical and added value, while encouraging other experiments or pilot projects later on that developed cultural capital in the Isan community and in university students as a base of creativity in contemporary performing arts.

Some of the impacts of the research project were tied to personal and community development. They were specifically applicable to learning and teaching, research, and creating contemporary performances from artistic capital rooted in Isan communities. They helped to create a learning arena and values which relate to the following dimensions: 


\section{Impacts on Participants: Creative and Social Skills Development,} Learning, and Change

The research project used ideas, practices and processes from Applied Theatre and Drama as its main tools (see Prentki and Preston 2011; Smith and Dean 2012). These tools helped to produce and promote skills and modes of understanding which generated creative social skills which could be used as cultural capital. Participants in the project learned and developed these skills by being involved in all aspects of the creation and presentation of the puppet performance, including staging it in many different venues. Their full involvement over a long period of time changed students' thinking, bodily comportment and movement, along with their thinking capacities. They produced useful modes of cultural capital which were, in Bourdieu's term (1986), embodied. Depending on their roles, some of these skills mattered more than others. The next section will specify the specific skills which different types of participants developed most as forms of cultural capital.

5.1 The six puppeteers developed skills in the many creative processes involved in puppetry, from designing the puppets to the weaving and assembling the puppets, to costume design, puppet mechanics and basic puppet movements. They also learned to sing folk songs, e.g. Mor Lam, Phaya, Sora Panya, to use their imagination for the puppet movements and characters, body control and style in acting, concentration, and the mind-body connection needed to merge with the puppets. More generally, they learned patience and became better able to control negative emotions, to show commitment and responsibility, time management, effective communication and teamwork, to respect others' opinions, and to be more able to express ideas beneficial to the task at hand, while listening and opening up to criticism. These are not just skills useful for artists but are transferable soft skills useful for most types of jobs or social interactions.

These diverse embodied skills developed in the six participants helped with performing, but they also proved to be useful in diverse social settings in and out of university. They learned the value of teamwork to solve problems and to complete tasks on time, but also to work for a community. Students gained more focus and to collaborate and brainstorm when facing new problems. Besides learning to make decisions for which they would be responsible, they learned to listen to reasons and were better able to express themselves. This contributed both to group working processes and to the coherence and flow of the final production. These skills also came into play in other classes taken in university, as well as in the greater confidence they gained to work with others outside of the university. 
The students involved in the project learned to use their local Isan dialect better. While five of them grew up in Khon Kaen city and one came from Chinese family, after doing this project they were much better in using the Isan dialect to communicate with one another and in performing for Isan audiences. This new skill was useful in their study of the dramatic arts, but it could also be applied outside of school, too.

By being able to create a unique performance and to transfer knowledge or practice a puppet show to others, especially to young people interested in puppet shows, all six participants could teach puppetry skills to new members who entered the group to perform.

5.2 The musicians learned to work systematically after their long practice sessions and collaboration process with the drama student puppeteers. The Sinsai Roo Jai Ton piece was the first project in which the Drama Department used Mor Lum music in a contemporary performance. This use of the music helped to tell the story and to create a distinctive local atmosphere and mood for the situations that happened on the journey portrayed in the play and permitted better interactions with the puppeteers. This project was the first to use music in this way so the musicians could seek for new opportunities to combine local music and contemporary performance. The musicians needed to adjust to some new behaviors, such as punctuality, focused training, planning for work and daily life, stamina, courage to express opinions and being willing to experiment with music. Long effort was spent on how to work in a modern drama way based on interpreting drama and performance. All of this was quite different from what the musicians were used to, but y going through this process they could better develop their musical skills and creativity outside of their zone of familiarity. It helped to link up with puppeteers so they could create an atmosphere to convey the ideas and imagination of the performance to the audience.

The musicians gained new knowledge and understanding shaping how they think about working with others and with creating music in performances by local music students. Tactics discovered from this research have been applied to other projects, including one by graduate students who developed a thesis on folk music in the project called Poom, which was presented to the public in May 2018, as well as being developed by second and third generations of musicians involved in the Sinsai Roo Jai Ton piece. These folk music students now have more courage to work outside the box of their training and to create new performances based on imagination and creativity.

5.3 For me, as the researcher, I learned many new things, beginning with the need to leave the safe zone of what I already knew and had done. Previously I tended to view my role as an academic in the university, and wanted to 
use ideas and reasons to convey knowledge to students through words. Being involved in this research project has helped me to see the value of learning through practice as an "artist-practitioner". This engaged form of learning in the arts led to various discoveries and opened up new areas for me to work.

Firstly, I realized that creating new work requires many kinds of practical skills grounded in making physical things and helping bodies to move so the performance comes to life. Working on this practice-focused path in the arts has generated wisdom through greater sensitivity, patience and imagination that permits me to work at full capacity. Using new practice-based "sensibilities" grounded in things and living bodies rather than ideas and theories have helped lead to better ways to communicate and richer aesthetic awareness. Work done for this group project often required listening to the ideas and views of others and working with them as partners in the project. Doing so has helped to reduce the role of ego for the better working process and results of the group for the project.

This research project also led me to realize that both my students and I have a lot to learn from rural Isan communities and artists. Although I grew up in such a community, in some ways my urban education slowly uprooted me from villagers and village life. By returning to work in a different community for this project, my students and I worked under Kru Siang's plan, and thereby learned to develop the arts - including the puppets - from scratch in ways no book or lecture could teach. By living with an elderly couple and helping them and their community produce the many different materials needed to make the puppets, we acquired a new experience of and appreciation for the way arts fit in to local community life, besides learning the many practices needed to produce art. These community-based artistic activities involved everyone physically and mentally, and required them to work with material practices to learn the village way of life and how the arts fit into them. This included everything from making colors to dying cloth and making baskets for the puppets' heads. We learned how different practical arts connected with one another such as seeing how Mor Lum, singing, verse writing and worked together to create the puppet performance. All of these experiences pushed my students and I into a different - and more refined and practiceoriented - way of understanding the arts in community life. We learned how art depends on deep forms of creative cooperation and problems often require teamwork and a sense of shared responsibility for outcomes as well as how to be patient and a part of the community. This also required us to learn about community taste and their preferences and how to adjust to them or to seek to alter them. 
A further impact concerned learning new things, including how to integrate the many creative practices needed to stage puppet shows. The little knowledge I had in this arena challenged me to learn new things from the bottom up, including new ways to work in the arts that differed from what I knew. By learning new ways of doing performance and applying this knowledge in theatre work by focusing on "practice," I came to understand how "art for development" was at the heart of applied theatre and drama. I saw more fully that working as creator, instructor, scholar, researcher, and facilitator in the project helped me to develop a deeper awareness of knowledge in the dramatic arts, such as acting, directing, design, and script creation. Yet since the research problem is the creation of puppet shows, I needed to select the right tools for the job, which required me to combine people and puppets with existing knowledge to produce new practices, skills and knowledge.

Finally, although I was someone from Isan living in northeastern Thailand, my education and my focus had separated me from Isan "values and spirit," and dissolved my connections to the region. This research project took me back to relearn or rediscover a lost or forgotten sense of Isan identity. It helped me to recover some of what I - and my students, too - had lost and to inject this recovered Isan spirit or cultural vitality into our contemporary performance. This result has had a direct and lasting effect on me by modifying my vision of what work in drama could be, and allowed me to turn my attention to Isan arts and culture in local communities and to seek for creative ways to present this practical community knowledge a contemporary look while still rooting it in Isan issues and life. It has helped me to generate a better understanding of both Isan communities and of myself, and to give Isan culture a new dignity. By infusing the performance with this dignity, out project could better tell a story able to engage the participating university students, as well as the local artists and audiences so they could enjoy a fresh look at the value of Isan cultural life.

5.4 The main artist, Kru Siang or Preecha Karun, was impressed by new ways to make puppets, to design the puppet mechanism, and by the new ways to move and to create characters. He learned to do new things from this research, too, so he could develop a new puppet show by the community Dek Thewda puppet troupe called Ong Ku Lee Man. The improved singing and music for this performance resulted in different puppet shows from those first done. Puppet training techniques were used to systematically help young people to learn how to show their puppets as they became new members in the troupe. Audiences who saw the puppet show Sinsai Roo Jai Ton followed up the work of the Dek Thewda puppet troupe. Although this specific puppet 
show ended, more people and government agencies have continued to express interest in the show, provided some funding, and have regularly visited his village.

Kru Siang added to the puppet value by making smaller version of puppets and selling them as souvenirs for tourists or interested agencies. These unique puppets are not only found on digital media or live performances, but they have now become a creative and valuable symbol of local Isan arts and culture, enhancing the incomes of the villagers beyond sales of their agricultural work as well as promoting the economy in the community with cultural capital.

Having university students with Kru Siang in his village helped him to design many new activities so the students could use their energy and their bodies to work as part of community they came to live and learn from. He also learned to schedule his work and take responsibility for his decisions and commitments. He saw that young people often had different tastes and interests from his own. This prompted him to try new ways to redesign and work with the puppets.

Impacts on the Khon Kaen University Performing Arts Program: Refocusing on Practical Learning with Community Artists

The experience of going out to work with and learn from local artists in surrounding communities has helped guide the design of the performing arts curriculum in drama at the Faculty of Fine and Applied Arts of Khon Kaen University. Among the new developments is our focus on sending out students to study, learn, and practice creative activities with local artists in nearby communities. This helps them generate direct experiences for students to learn about the different local arts, principles, concepts, and thought bound up with various types of performances before they try to create contemporary performances in the classroom.

I have used these methods to organize the teaching and learning of different subjects, such as applied theatre, Isan folklore and storytelling, Isan identity in the performances, and drama projects for development. In each case, this working process has made the students attentive, determined, and energetic, and permitted them to become more discipline and patient as they step out to learn the performing arts outside of the classroom.

By learning the fundamentals of Isan arts and culture with local artists, students changed their views and working habits in drama, since they no longer see Isan arts as something ancient and distant from their lives. They learn to see local arts as valuable cultural forms that folk artists have inherited, accumulated and transferred through the shows, and students can then absorb the 
teachings and thought of Isan people and learn how to communicate it through practice. In addition, the care and attention of teachers towards students has allowed drama students to experience the generous spirit of Isan people and to include it in their creative work, such as work by the first class of students in the drama department called Pon Pla Nai Pa Khao Noi by Ratchaneekorn Jantaharn, Phutthaphon Nonpla, and Marisa Wattanawichai. They brought the northeastern Thai literary text Pla Bu Thong to retell and interpret y linking it to issues in current Isan families. The drama was presented in a hybrid style using the northeastern way of life and the performing arts in the drama, such as Mor Lam or northeastern folk music, and it reached northeastern audiences well whether performed in the form of a touring theatre or stage drama in the theatre.

Theatre in the Isan folklore class and for storytelling drama students in the second class of students of the drama department used Isan folk tales and legends such as Nang Yai - a folk legend from Mahasarakham Province and Thao Ched Huad Ched Hai to interpret. They presented them in a modern dramatic form through the main ideas and actions of the characters. The Yai Lao Lhan Wa project also allowed drama students to explore and recover neglected parts of Isan culture through action in performing dramas. Isan identity in the performance of drama students in the third class of drama students who visited the area to learn with artists in the community and to create a performance in the form of museum theatre and experimental performance. These teaching and learning methods have allowed new modes of learning rooted in practice and experiment, so students have developed their works based on new principles and discovered new ways of creation. They can also use their skills, knowledge, and imagination in a variety of contemporary performing spaces.

\section{Impact Seen in the Development Tools for Youth in Isan Primary Schools}

The contemporary puppet show Sinsai RooJai Ton has made an impact on children, youth, and students in primary schools in Khon Kaen Province who watched the puppet performance. The performance led to a workshop called Puppet Show Sinsai Arousing Youth in Khon Kaen City. The concept of the puppet show was to promote and develop students in schools such as Thung Bo Witthaya School in Khao Suan Kwang District and Ban Sawathee primary school (Savatthi Rat Rangsarit). Ban Sawathee School has Mor Lam Hoon Sinsai Noi Roi Pee and the school wanted to develop ways to play or perform a puppet show. Dr. Pornrat Damrhung and I were joined by a drama student in this 
research project, Pongsathorn Phuttakot. We held a workshop to develop puppet shows for students at Ban Sawatee School by using exercises from this research, such as

- Coordinating the movements and the breathing of the puppets and the puppeteers. This unity that must also include common breathing patterns;

- Practicing the coordination of breathing, looking, walking, sitting, and basic emotions, such as agreeing, embarrassment, sleepiness, boredom, love, responding to others, conflict, anger, excitement, fear and tiredness;

- Ensuring the puppeteer concentrates and focuses on the puppets, so she finds the strength and specificity for each type of puppet;

- Working with puppet partners over time so there is coordinated interaction among puppets and puppeteers onstage, in two and more characters; this will permit them to speak to each other and to send, listen, move when speaking, silence when listening, and for working in a group.

The puppet performance story for this workshop was also adjusted so the show has a line of actions with conflicts and battles. It was shorter and more suitable for youth. The presentation format and directing permitted the puppet shows by the youth have a clearer direction. After this training workshop, the students' puppet show at Ban Sawathee School was livelier and more enjoyable, showing the value of workshops with students of all ages.

\section{Impacts on Creating Researchers: Extending and Developing Performance Research}

The experience of the Sinsai Dek Thewda research project has helped to drive further research projects focusing on practical, creative work. I proposed the project "Sud Sanan - Sawatthee: Creating contemporary performances from cultural capital for connecting collective memories and values of Isan community" 7 to the board of the Faculty of Fine and Applied Arts and received funding from the Academic and Research Department to conduct research project for the year 2018-2019 to continue doing performance research. I sought knowledge in Applied Theatre/Drama through a creative process involving contemporary performances by using keywords for developing research problems tied to "shared memories" and the "contemporary Isan way of life," and by using community arts and culture as a base for designing drama activities and developing contemporary performances.

7 The research project supported by Faculty of Fine and Applied Arts Research Found, fiscal year 2017 . 
This Sud Sanan - Sawatthee project has focused on participatory action between local artists, villagers, community youth, and drama students in the Sawathee community area, seeking memories and values of the Isan community that could be developed into drama-based activities in the community for villagers to see and share experiences, views, and inner voices on changes in contemporary Isan society. For this, many villagers came to see and exchange their ideas, feelings, experiences, and memories they perceived and learned from the performance. This performance sought to identify and to embody onstage the views and identities of rural Isan people today who are between "old Isan and new Isan," and the changing Isan society around them.

The performance combined narratives of truth, imagination, myth, and belief through the perspectives and interpretations of participants, using Mor Lum, Sorapanya and folk music based on traditional and non-traditional styles to help communicate to them. Principles from modern drama were used to create meaning in the lyrics and music. The performance describes events in the villagers' experience and alternates with poems and lyrics using actors' bodies in motion and creating images onstage to convey locations, characters, and events. The use of rituals within the performance, i.e. making Krathong to exorcise bad spirits, permits the performance based on storytelling to engage theater so it can communicate and highlight some of the hidden or neglected issues in contemporary Isan society.

Sud Sanan developed from the Sinsai Dek Thewda - Khon Kaen University project to create an experimental space for contemporary performing arts for arts in the community. It involves the interaction between an educational institution and the community, between the artists in the community and university instructors, between rural villagers and urban students, all of whom interact on same platform, even though they differ in terms of their specific problems and starting points. Even though the performance is rooted in art and culture, the presentation style shows the creativity of researchers who work on issues and in ways that were missing from previous research.

\section{Impact on Khon Kaen University: A New Venue for Contemporary Performing Arts in Isan}

Work on Sinsai Roo Jai Ton in the Sinsai Dek Thewda project permitted me to continue this type of research in new projects in Khon Kaen University. This opened up new spaces for contemporary performing arts rooted in Isan cultural life. This interested both university administrators and local officials. They see the arts and culture are one of the main strategies of create value for 
the university and local Isan society. When I proposed a project that developed from the Sinsai Ru Jai Ton called the "Isan Art Innovation Project, Isan Art Exploration Creates a Contemporary Puppet Performance," they supported it since it sought to use research knowledge to develop modern Isan puppet shows which would permit students from all faculties to participate.

The goal of this new project is to create a learning zone for Isan arts and culture for Khon Kaen University students where they could create a contemporary puppet performance. We are using two types of puppets. First, there are three shadow puppets or Nang Pa Mo Thai, two in traditional Isan styles - large ones and small ones, both made of cow skin - and new tiny shadow puppets made of cardboard. Second, there are new style of folk rod puppets made of sticky rice basket and wickerwork like we did in Sinsai Dek Thewda. Like in the Sinsai Roo Jai Ton performance, we focus on the Sinsai character, but the new project explores a different episode, namely that of "Nakyuthakarm," the "Battle with the Naga," which relates Sinsai's descent to the underworld to retrieve Sumontha's daughter where he fights Warun Naga, the king of the underworld. During the battle between Sinsai and the Naga, a Garuda helps Sinsai defeat the Naga. Although Sinsai is offered control over the underworld city, he refused, and so returned it to the Naga after teaching him to govern the city morally.

The "Isan Art Innovation Project" is like the Sinsai research project in that it seeks to bring young people and students from the city area to learn Isan art and culture through collaborative work processes with local artists, including Kru Siang, Preecha Karun and Sombat Yodpratum (Pamotai Pong Peng Sud Sa Naeng Team), and experts in music and acting, like Professor Pornrat Damrung, Sinnapa Sarasas, and Arthit Krachangsri. But the new project differs from the old one in that we are now seeking new strategies to create and present contemporary Isan puppet shows at Khon Kaen University.

Another project emerging from the Sinsai Dek Thewda project that received funding from Khon Kaen University was a pilot project to discover effective strategies, forms of knowledge and creative skills in contemporary performance that are rooted in Isan artistic cultures. This "Thai-ASEAN Contemporary Theatre and Performance Project, Moving Isan" seeks to open creative spaces for artists, teachers, and students of music and performance to experiment with developing short performances in different styles and methods of presentation, such as dance, music, acting, storytelling, and stage plays. The main idea of this project was to make contemporary performing arts experiences for Khon Kaen University students through collaborations with artists and experts in music and performance to help generate ideas, techniques, and knowledge through practice. Performances from this project were contemporary shows that used different strategies to engage creators, curators, and artists 
in their knowledge to work outside patterns or to use current knowledge to create new types of performance. The pilot project led participants to learn new concepts and modes of performing from problems and practices, focusing on training, discussion, conceptual discussions, and collaborative action. The project produced performances such as Nang Pom Hom, a type of contemporary Isan music, Hom Hued Hueb (or Strive) performance, storytelling with local singers, Naga Bu Cha, a contemporary puppet show, and Sud Sanan with the revised presentation of clear direction and more complete light and sound elements.

These developments show how the Sinsai Dek Thewda project created an impact in Khon Kaen University that has helped generate new practiceoriented research projects of similar types in the creative arts.

\section{Impact on Building Transnational Networks: Connecting People and Cultures through Isan Puppetry}

The Sinsai Dek Thewda project also created spaces and networks for local Isan contemporary performing arts in foreign countries. Troupe members performed and ran creative puppet training workshops for young people in Vientiane, Lao PDR and Ho Chi Minh City, Vietnam Socialist Republic. These were the first trips across the Thai border to neighboring countries in Southeast Asia for the team.

The Sinsai Contemporary Puppet Performance Project on Both Banks of the Mekong helped spread creative puppetry to several locations in Vientiane, including the Vientiane Children's Cultural Center and the Faculty of Language and Culture, National University of Laos and to exchange knowledge on how to do puppet shows with Jampa Laos Puppet Troupe from the Vulnerable Youth Development Association (VYDA LAOS). The Sinsai legend is a part of Laos' national literature and used to teach thinking and knowledge of Lao culture to young people from elementary school to universities. Our performance of Sinsai Roo Jai Ton was a form of storytelling about Sinsai in a new perspective since it was related to new content that emphasized "unity, sacrifice and patience as tools to produce success." The new Sinsai Roo Jai Ton story impressed the people of Laos and provided them with a different way to re-tell old stories for people living today. Since we used a form of Isan language in our dialogues and lyrics that resembled the Lao language, Lao people could understand what we were singing, saying and showing quite well.

We also performed at the In \& Out Peace Arts Festival 2018 in Ho Chi Minh City. This included drama troupes and artists from many countries, including Thailand, The Philippines, Indonesia, Singapore, Taiwan, Germany and Brazil. 
We shared our work and held workshops in communities with educational institutions from early childhood to higher education, both in the city and outside it. Before visiting various educational institutions, the project organizer allowed the drama teams to present and discuss their performances in the hotel, so we got to see different designs and uses for puppets, shadow puppets and forms of storytelling. This sparked new ideas among artists participating in this event.

The Sinsai Roo Jai Ton puppet performance also received a lot of attention from artists, young people and the public, including local Vietnamese media, who showed it on various TV programs. Although the audience could not understand the Isan language used in the performance, it effectively communicated the story through the movement, sounds, and actions of the puppets. This permitted the audience to understand it and respond to its humorous, exciting, and sentimental parts. The unique puppets made with distinctive bamboo materials and wickerwork reflected a rural society and an agricultural way of life still familiar to many people in Southeast Asia. This contemporary Isan show rooted in traditional art forms provided a common cultural reference point able to connect with the cultural spirit of audiences in the region and beyond despite our different spoken languages.

During the time of the project we have shown the puppet performance, held workshops and joined art festivals with many puppeteers, artists and theatre troupes from various countries. The artists involved in the project used their cultural capital to create puppetry and performances which could present and identify the characteristics of their own country, nationality and ethnic group through storytelling, singing, music, costume, dance and movement. The local cultural capital developed through this project differed in its aesthetics and values with others we have seen in other places. But the methods and working processes can be used to create new performing arts work and provide a creative space for a distinctive form of human cultural diversity.

Among the many different types of puppetry current in the world like those in our project, I discuss three here. First siwaWAN (abbreviated from Sinema Wayang Kewan) comes from the Sang Pamarta Indonesia Foundation. It is an interesting and creative puppet show based on "wayang kancil" (traditional animal-skin shadow puppetry) using a multimedia atmosphere to tell stories of animals. Silhouettes are the focus in this show, with the music and multimedia lighting supporting the drama. The show was created by the Sukoharjo-based Central Javanese puppeteer Wahyu Dunung Raharjo, who in 2011 won a young puppeteer competition in Indonesia, and his sister, Selvi Tri Hapsari, who is a traditional singer and traditional musician. Second, 
the Brazilian "O Que De Que" puppet troupe used the myth and storytelling of local Brazil culture to create a puppet show based on Robert Louis Stevenson's adventure novel Treasure Island. This wordless, but exciting, solo puppet performance tells the adventure story of Jim Hawkins. He goes through many adventures, ranging from meeting an old wolf from the sea to winning a treasure map to meeting winds the seas while on a huge ship, to facing pirates, and overcoming the dangers of a deserted island, to meeting a ghost, and finally to discovering his treasure. A third troupe is the Taichung "Sheng Wu Zhou" shows many puppets from Taiwan's past and introduces Taiwanese traditional puppets, including the Taiwanese Jin-Guang, television-style puppets and the Q-version. In its "The Juggling" there is Taiwanese kung-fu, which lets audiences know more about Taiwan's puppet cultures. We were glad to develop this project as part of an exciting world of puppetry for young people.

Beyond developing new academic and research, creative arts research develops performances, such as created by Roselina Johari Md. Khir (see Asmawi 2017). She explores the interactions with indigenous young people in East Malaysia (Sabah) and the assimilation of urban youth into understanding a world different from their own via script writing and stage performances. Her practice-oriented research process focuses on making performance from stories, folktales, community's legends to produce cultural capital that is useful for new arts work, whether for puppet performances, creative arts or research projects that focus on developing young people, communities and making creative spaces for learning various arts and cultures.

\section{1 \\ Conclusions}

The diverse impacts of the "Sinsai Dek Thewda" research project, which ran from 2017 to 2019, appear on different scales, ranging from the community to the local and regional level, and from there to the national and international levels. Besides producing an original puppet performance which was performed more than 40 times by the Isan students and local artists who created it, both in Thailand and abroad, and on various media channels, the project also attracted diverse audiences throughout its evolution, who also became interested in the research and its results. It inspired and generated creativity that expanded and developed in the community and produced value for research in the creative economy, showing its new knowledge had tangible benefits for many. 
The research project focused on embodying community arts and culture as a form of cultural capital for participants to create valuable contemporary performances. They learned to combine local Isan arts of storytelling, Mor Lam, Hoop Taem (Isan mural-painting), dance, music, and traditional folk performances with some modern theatre theories and techniques. They developed creative performance techniques through experimentation, based on working processes that produced practical life skills and creative productions. The process started from self-confidence which it then connected to local wisdom and an imaginative mind able to produce creativity as the heart of artistic work. This research project's many impacts included:

- Creating a new community-based learning arena beyond the university classroom. This provides students with direct experiences with artists, thinkers, and villagers, along with new active learning opportunities;

- Developing cultural capital in communities and among students for contemporary performances, so they could create new scripts based on stories, tales, legends, ways of life, and link them to contemporary issues in the community, and gain experience in combining them with a Mor Lum lyrics, and new Isan folk music made with local instruments. This work was contemporary and relevant to the performances, and conveyed the thoughts and sounds to Isan audiences well; and

- Experimenting with new ways to combine modern drama techniques and ideas with local Isan community concepts and practices. Teachers and students were eager to be involved in the community arts project and the still seek new knowledge and strategies for creating relevant performances, and new ways to embody Isan identity in contemporary performances by interpreting the symbols, and movements that reflect the heart and spirit of Isan people. The above impacts helped to develop students, local people, materials, traditions, and spirit of Isan as part of a robust cultural ecology in northeastern Thailand. By working through education, community connections, and a network of folk artists, this practice-based approach in the performing arts provides a new source of vital creativity in contemporary Isan. It shows how research based on artistic practices can connect communities, artists, and universities while generating new knowledge, skills and opportunities as $21^{\text {st-century cul- }}$ tural capital for growth and sustainability.

\section{Acknowledgement}

The author wishes to thank the two outside readers' comments of an earlier draft, which improved the current version of the paper. 


\section{References}

Asmawi, Adelina, ed. 2017. The Art of Creative Research. Kuala Lumpur: University of Malaya Press.

Barrett, Estelle, and Barbara Bolt, eds. 2007. Practice as Research: Approaches to Creative Arts Enquiry. New York: Palgrave Macmillan.

Bourdieu, Pierre. 1986. "The Forms of Capital." In Handbook of Theory and Research for the Sociology of Education, edited by John Richardson, 241-58. New York: Greenwood Press.

Damrhung, Pornrat. 2018. "Sinsai and Self-understanding: The Use of Imagination and Memories in Story Theatre Performance." Journal of Music and Performing Arts 1 (1): 129-42. (in Thai).

Damrhung, Pornrat. 2019. "Introduction." In Performance Research in Cultural Ecology, edited by Pornrat Damrhung, et al., 8-48. Bangkok: Phap Pim. (in Thai).

Prentki, Tim, and Sheila Preston, eds. 2011 The Applied Theatre Reader. New York: Routledge.

Smith, Hazel, and Roger T. Dean, eds. 2012. Practice-led Research, Research-led Practice in the Creative Arts. Edinburgh: Edinburgh University Press. 